\title{
VERPLEEGKUNDIGE BERAMING VAN DIE BEHOEFTES VAN MOEDERS MET VOORTYDSE BABAS
}

\section{Roets}

\section{OPSOMMING}

Voortydse baring is en bly' $n$ wesentlike probleem. Daar sal altyd moeders wees wat midde die krisis van $n$ yoortydse baba is.

Die unieke behoeftes van hierdie moeders bly tans onvervul in Moontlike rede hiervoor is dat daar tans nie " $n$ volledige beraming deur die verpleegkundiges in die neonatale intensiewesor $\%$, die spesiatesorg eenhetd of in die nageboortesaal gedoen word nie.

Verpleegkundiges is gesteld op die fisieke behoeftes van moeder en baba tydens haspitalisasie en skenk oonwegend hieraan aandag. Die behoeftes wat agterweë getaat ward, is juts die wat by die moeders " $n$ groot rol te speel het.

In die studie is daar dan aan die behoeftes, anders as die fisieke, aandag gegee.

\section{SUMMARY}

\section{Premature labour is and remains an actual problem. There will atways be mothers} that undergo the crisis of having a premature biaby.

The unique needs of these mothers remains unfulfitled. Possible reasons for this are that the nurse, working in the neonatal intensive care, special care units or in the past natal ward, does not do a complete assessment of the mother.

Nurses are set on the physical needs of the mother and baby during hospitatization and pay more attention to these needs than to others. Those needs which are in fact neglected, are those which are so crucial and important, concerning the mother.

In this stucty, it is needs, other than physical needs, which are emphasized.

\section{INLEIDING}

Die geboorte van ' $n$ voortydse baba is ' $n$ onverwagte en traumatiese gebeurtenis vir 'n moeder. Die ouers berei lank voor vir die vreugde om hul baba in hul arms vas te hou en te vertroetel, en skielik, dikwels sonder waarskuwing, word hierdie lank verwagte rol deur geneeshere, verpleegkundiges en masjienerie in 'n neonatale intensiewesorg eenheid vervul en word die ouers in die versorging van hul kind uitgesluit. Die onvervulde rolverwagting lei daartoe dat die ouers van voortydse babas spesifieke behoeftes ontwikkel. Praktykervaring en interkollegiale gesprekke bevestig dat die moeders besondere behoeftes het en dat daar tans nie voldoende aandag hieraan gegee word nie.

Al het die oorlewingsyfer van voortydse babas weens verbetering in Neonatale intensiewe mediese sorg drasties oor die afgelope twee dekades verbeter, (Lee, Penner \& Cox, 1991:105; Collin, Halsey \& Anderson,
1991:115), bly daar nog steeds baie moeders wat die krisis beleef. Grieve (1990:24) beweer dat die verpleegpersoneel ' $n$ baie belangrike rol in die verbetering van interaksie tussen 'n moeder en 'n voortydse baba kan speel. Dit kan egter alleenlik geskied indien 'n deeglike beraming van die moeders se behoeftes gedoen word.

\section{PROBLEEMSTELLING}

Die probleem van 'n moeder met 'n voortydse baba begin as gevolg van die onvoltooidheid van haar swangerskap. 'n Swanger pasiënt ondergaan sekere fisiologiese sowel as psigologiese veranderinge tydens die drie afsonderlike trimesters van swangerskap. Gedurende hierdie drie trimesters word die moeder sistematies vir moederskap voorberei.

Die derde trimester van swangerskap is veral die tyd waarin die ma haar vir die proses van baring voorberei asook die finale voorbereidings vir die koms van die baba tref. In hierdie tyd word die baba vir haar 'n werklikheid en sy spandeer byvoorbeeld baic tyd om 'n geskikte naam vir die baba te vind, 'n babawiegie voor te berei en kleertjies aan te skaf (Olds,London \& Ladewig,1988:326).

Wanneer ' $n$ baba voortyds gebore word, word die voorbereidingsproses onderbreek en ontstaan spesifieke behoeftes by beide ouers As gevolg van praktiese probleme om die vader deurentyd te betrek, beklemtoon die studie die behoeftes van die moeder.

Uit bogenoemde bespreking blyk daar dus 'n wesenlike probleem te wees, naamlik dat onvoltooide voorbereiding aanleiding gee tot die ontstaan van spesifieke behoeftes by die moeder.

\section{NAVORSINGSDOELSTELLING;}

Die navorser wil die unieke behoeftes van moeders met voortydse babas identifiseer ten einde die verpleging van diesulkes tc bevorder.

Vir die doeleindes van hierdie studie het die navorser nie in die beraming aandag aan die fisieke behoeftes geskenk nie. Die doel hiermee was nie om die moeder se fisicke behoeftes te misken nie, maar is die navorser van mening dat die emosionele impak van hierdie gebeurtenis die fisieke behoeftes tot ' $n$ ondergeskikte rol reduseer. Fisieke behoeftes kan verder ook maklik deur middel van ' $n$ vraelys beraam word en is ook reeds duidelik in die literatuur uitgespel. Dit het as motivering vir die weglaat van fisieke behoeftes gedien.

\section{ONTLEDINGSEENHEID}

Die ontledingseenheid is saamgestel uit moeders van voortydse babas in 'n akademiese hospitaal in Bloemfontein. Die respondente is deur 'n nie- waarskynlikheid gerieflikheidseleksie bekom en die aantal persone is deur saturasic bepaal (Burns \& Grove, 1987:749). Die insluitingskriteria was

- blanke vroue;

- voortydse babas tussen 28 en 36 weke swangerskapsduur;

- 'n hospitaalbevalling en 
- die baba moes in die neonatale intensiewesorg - of die spesialesorg eenheid verpleeg word.

Die ontledingseenheid het uit 20 respondente bestaan.

\section{NAVORSINGSTRATEGIE}

\section{Navorsingsont werp}

' $n$ Kwalitatiewe ontwerp is gebruik en ' $n$ verkennende sowel as beskrywende studie om die behoeftes van moeders met voortydse babas te identifiseer, is gedoen.

\section{Metode van data- insameling}

'n Gestruktureerde onderhoud is tydens die eerste kontak met elke moeder gevoer om die sosiografiese data te bekom. Hierna is vryhoudingsonderhoude aan die hand van ' $n$ skedule met elke moeder gevoer. Die doel van die skedule was slegs om as kontrole te dien ten einde alle relevante onderwerpe te dek en om die subjekte tot gesprekvoering te stimuleer (Mouton, Ferreira, Puth et al. 1988:139). Daar is altesaam drie onderhoude met elke moeder gevoer. Die eerste is sewe dae na die bevalling gevoer omdat die moeder dan midde in die krisis is en die meeste moeders dan nog gehospitaliseer is, die tweede binne veertien dae na ontslag van die moeder aangesien daar dan skeiding tussen moeder en baba is en die laaste binne sewe dae na ontslag van die baba aangesien die moeder en baba dan herenig is en die moeder self vir die versorging van die baba verantwoordelik is.

\section{Metode van data analise}

Nadat elke onderhoud gevoer is, is die gesprek wat op band geneem is, getranskribeer. Die getranskribeerde gesprek is bestudeer en alle data is in kategorie ë volgens die werklikheidsaspekte van die mens geplaas aangesien die navorser se filosofie hierdie beskouing onderskryf en ook omdat die behoeftes wat uitgespreek is outomaties in die kategorieë geval het. Die kategoriee is daama in groepe en temas onderverdeel, afhangende van elke respondent se besondere behoeftes. Dit is gedoen om die groot hoeveelheid data en komplekse inligting te reduseer tot selektiewe en eenvoudige inligting wat maklik verstaan kan word (Miles \& Huberman, 1984:21).

Figuur 1 is 'n voorstelling van hoe datareduksie t.o.v. die behoefte aan inligting plaasgevind het.

Soos in Figuur 2 weerspiëcl word, was die analise 'n lang proses $w$ at deurlopend plaasgevind het. Die bandopnames is dadelik na elke gesprek getranskribeer en geanaliseer en herhaaldelik gespeel ten einde waninterpretasies te voorkom. Daar is gedurende die data- insamelingsproses reeds met analisering begin sodat data-insameling en analisering ' $n$ interverweefde proses was (Miles \& Huberman, 1984:49).

\section{GELDIGHED}

Die beste kontrole vir die geldigheid van kwalitatiewe navorsing is die presiese aanwending van spesifieke standaarde by die versameling van data in die veld. Die navorser se praktykervaring in onderhoudsvoering het ' $n$ hoë standaard by die versameling van data verseker. Die navorser het self alle data versamel om die geldigheid verder te verhoog.

Geldigheid is verder verhoog aangesien die navorser met 'n oop gemoed die veld betree het. Sy het geen vooropgestelde idees gehad nie en oorweging is aan alle data geskenk (LoBiondo-Wood \& Haber, 1990:203).

\section{BETROUBAARHEID}

Sandelowski (1986:33) is van mening dat die klem in kwalitatiewe navorsing op die uniekheid $v$ an elke menslike situasie $v$ al en dat 'n herhaling van 'n studie dus nie moontlik is nie. Verifiëring sal dan die kriteria vir presiesheid wees. Verifiëring is dieleiding van 'n ander navorser wat die besluitnemingsproses van die oorspronklike navorser gevolg het om tot dieselfde of gelykstaande gevolgtrekkings te kom nadat dieselfde stel data aan hom verskaf word. Hierdie beginsel vir betroubaarheid by kwalitatiewe navorsing word ook deur Wilson (1989:475) en Kirk en Miller (1986:14) ondersteun. Dic navorser het sewe getranskribeerde gesprekke aan twee domeinkundiges vanuit die psigiatriese veld gegee om die onderhoudsvoeringtegnieke sowel as die behoeftes van die respondente te evalueer en te identifiseer. Beide domeinkundiges is vertroud met die navorser se filosofiese uitgangspunt. Die kundiges het tot dieselfe of soortgelyke gevolgtrekkings as die navorser gekom.

\section{RESULTATE}

\section{BEHOEFTES/PROBLEME MET BETREKKING TOT INLIGTING}

As 'n holistiese benadering in die versorging van 'n pasiënt gevolg word, moet daar aan die mens se behoefte aan inligting voldoen word Volgens die Suid-Afrikaanse gemenereg is dit die reg van elke persoon en het elke pasiënt dus die reg op inligting omtrent sy siektetoestand (Nel, 1989:36). Die moedervan 'n voortydse baba het hierdie reg aangesien die voortydse baba nie vir sy eie gesondhied verantwoordelik gehou kan word nie. In tabel $1 \mathrm{kan} u$ egter sien hoe dikwels die behoefte aan inligting aangespreek is.

Die navorser het bevind dat moeders spesifieke inligting oor die apparaat wat by die baba gebruik word, wil hê. Die respondente in die studie het die apparaat skrikwekkend gevind en wou daarom 'n verduideliking in verband met die doel en werking daarvan hê.

Vir respondente was dit belangrik om meer inligting in verband met die toestand van die baba te kry. Hulle wou ook, net soos in die geval van die studie deur Norris en Grove (1986:194-199), die presiese waarheid oor hul baba se toestand weet. Respondente wil die versekering hê dat hul babas sal leef. Aangesien die dood ' $n$ realiteit is, het $90 \%$ van die respondente inligting hieroor nodig geag.

Alle ouers vrees breinskade by die baba en ouers van voortydse babas het 'n verwagting dat hul baba dalk abnormaal kan wees. Respondente wou weet of hul babas breinskade het, abnormaal is en of hul mylpaalontwikkeling stadiger gaan wees. Dit is in teenstelling met Lee, Penner en Cox (1991:107) se bevindinge dat die ouers van voortydse babas nie glo dat hul babas ontwikkelingsprobleme kan hê nie.

Moeders in die studie het, net soos in die studie van Sammons en Lewis (1985:129) hul babas met voltydse babas vergelyk en tot die slotsom gekom dat hul baba nie in die normale model inpas nie. Perlman, Freedman, Abramovithch et al. (1991:516) bevestig dat moeders nie algemene inligting aanvaar nie, maar dat hulle gedetaileerde inligting oor die spesifieke prognose van hul baba verlang.

Moeders is bewus daarvan dat suurstofbehandeling tot blindheid (retinofibroplasie) en sekere antibiotika tot doofheid by die voortydse baba kan lei (Sammons \& Lewis, 1985:5). en wou meer inligting oor hierdie moontlikhede hê.

Borsvoeding en die problematiek rondom 'n voortydse baba se voeding is ' $n$ ander aspek wat in die beraming na vore gekom het. Weke mag verloop voordat die baba die eerste keer aan die bors kan drink. Dit het tot gevolg dat die moeder deur uitmelk, melk moet voorsien. Respondente wou baie graag meer inligting oor die tegniek van uitmelk asook oor die beskikbare apparaat hê. Die tegniese aard van die prosedure laat die moeder soos 'n tegnikus voel, hoewel sy tog voel dat dit iets is wat net sy kan uitvoer. Sammons en Lewis (1985:78) bevestig hierdie behoeftes.

Respondente was van mening dat die verpleegpersoneel nie altyd die hulp verleen het, asook die kennis gehad het om hul pasiënte tot suksesvolle borsvoeding te motiveer nie. Die inligting wat oor borsvoeding gegee is, was inkonsekwent en respondente het gevoel dat hul borsvoeding juis hieroor misluk het.

"Waarom het ek in kraam gegaan?" is 'n vraag wat deur 16 van die 20 respondente geopper is. Sammons en Lewis (1985:29) bevestig dat die etiologie van voortydse baring die moeders onseker maak oor die toekoms en dat hulle daarom meer inligting wil hê. Inligting omtrent die hantering en herhaling van voortydse baring (Perlman et al. 1991:512-517), is vir die moeder van belang. Die navorser het bevind dat te min inligting or die etiologiese aspekte van voortydse baring vir respondente 'n krisis is, omdat hulle skuldgevoelens toeneem indien hulle nie hul toestand medies kan verklaar nie. 


\section{KATEGORIE}

\section{GROEPE}

\section{TEMAS}

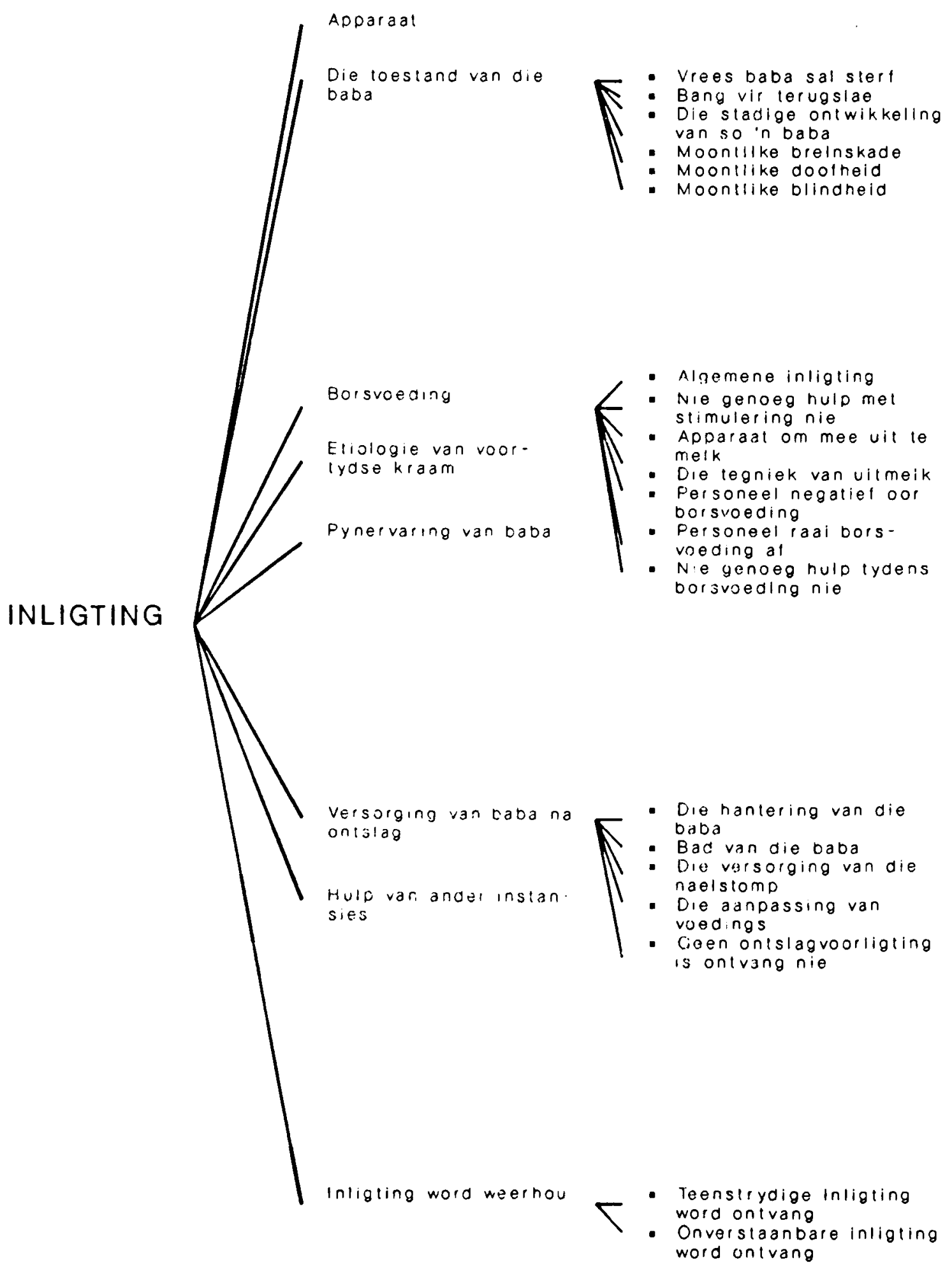

FIGUUR 1: Behoeftes/probleme met betrekking tot inligting 


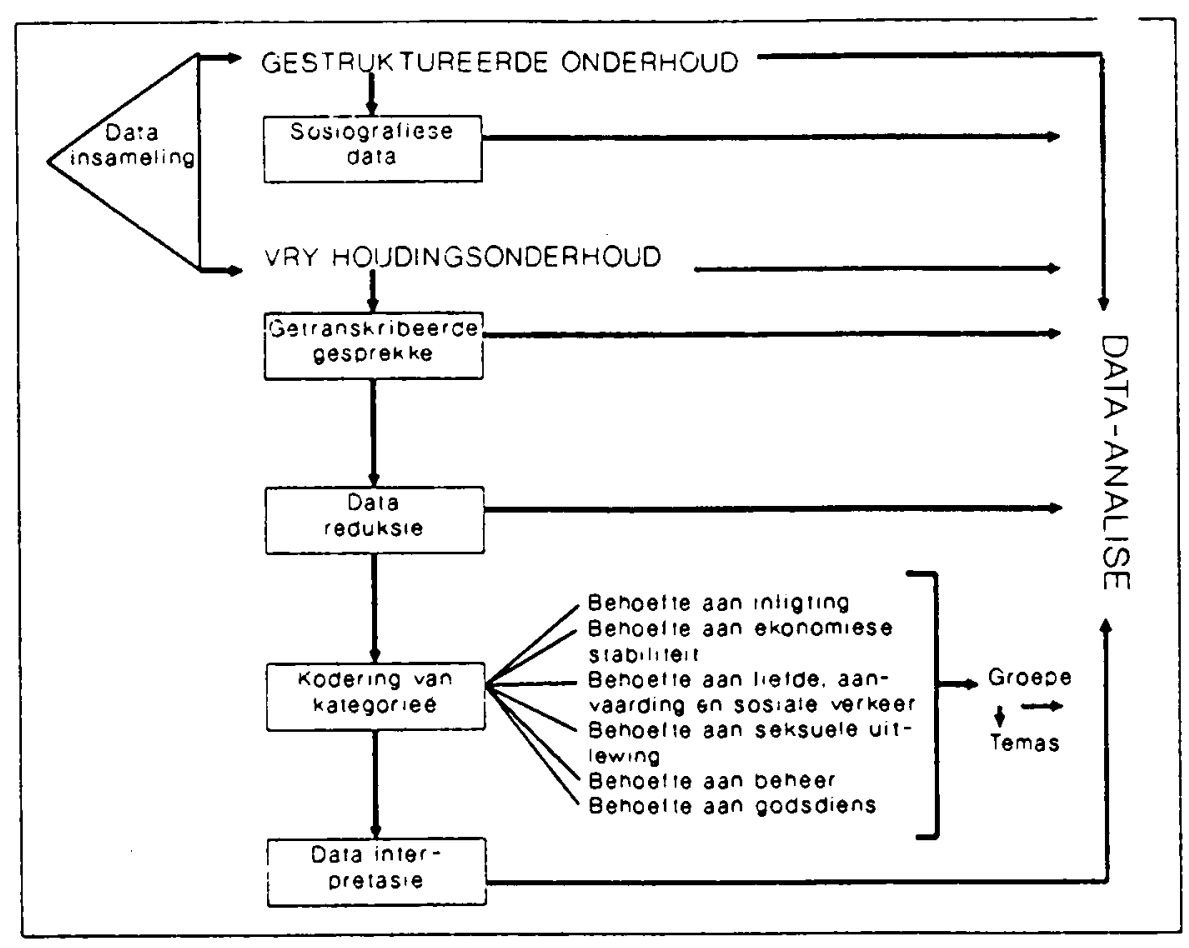

FIGUUR 2: Skematiese voorstelling van die dataversameling en analise proses

Die verwagte resultaat van goeie sorg, d.m.v. die verpleegproses impliseer 'n pynvrye pasiënt (Yura \& Walsh, 1982:299). Pynvryheid is die behoefte van elke mens en die moeder van ' $n$ voortydse baba ervaar die pyn van haar baba, pynlik. Respondente wou meer inligting omtrent stimuli van hul baba hê en veral of dit pynlik is al dan nie.

Nadat die ouers aangepas het by die idee dat hul baba in die neonatale intensiewesorg eenheid verpleeg word, ondervind hulle weer 'n disekwilibrium wanneer die baba ontslaan word (Auvenshine \& Enriques, 1990:789). Die mate waartoe die ouers ontslaggereed is (Sammons \& Lewis, 1985:179) sowel as die gemengde gevoelens van verligting, vrees vir die onbekende en hulpeloosheid van die moeder (Kolotylo, Parker \& Chapman, 1991:147-150) word dikwels misken. Die verpleegkundige speel 'n belangrike rol om die moeder op haar gemak met haar baba te laat voel sodat sy sonder angs in sy behoeftes kan voorsien (Olds et al. 1988:912). Sestien respondente het geen ontslagvoorligting ontvang nie en het die behoefte aan inligting in verband met die versorging van hul baba na ontslag geïdentifiseer.

Uit die literatuur blyk dit dat dit moeiliker is om voortydse babas as voltydse babas te versorg (Turner, 1988:162; Sammons \& Lewis, 1985:196) en daarom is daar 'n besondere behoefte by hierdie moeders om babaversorging aan te leer (Bliss-Holtz. 1988:24). Respondente het gesê dat hulle nie geweet het hoe om hul baba te bad, te hanteer, die naelstomp te versorg en die voedings aan te pas nie. Ten spyte van die feit dat daar baie verpleegkundiges is wat oor die nodige kennis beskik, het respondente so 'n groot behoefte an inligting gehad dat hulle dit nodig geag het om by ander instansies vir hulp aan te klop. Dit is die verantwoordelikheid van die gesondheidspersoneel (verpleegkundige ingesluit) om 'n moeder met ' $n$ voortydse baba se behoefte aan inligting te identifiseer en aan te spreek ten einde die baba in totaliteit te verpleeg.

\section{BEHOEFTES/PROBLEME MET BETREKKING TOT EKONOMIESE STABILITEIT}

Aangesien elke individu se finansiële posisie uniek is, behoort die pasiënt betrek te word by die beraming van moontlike probleme. Verandering in, of die gedwonge beẽindiging, of soos in die geval van die moeders in die studie, die vroeë, ontydige en tydelike beëindiging van haar beroepsbeoefening, kan nie net tot finansiële probleme lei nie, maar dit kan haar finansiële en sosiale sekuriteit as 'n lid van die gemeensk ap beinvloed (Minshull, Ross \& Turner, 1986:646). In Tabel 2 word weergegee hoeveel response oor die aangeleentheid by respondente teenwoordig was.

In die navorsing is bevind dat respondente baie bekommerd oor hul hospitaalonkostes was. Alhoewel alle respondente in die studie aan 'n mediese fonds behoort het, was hulle tog bekommerd oor die voordele (Funch \& Mettlin, 1982:96) wat hulle fonds bied. 'n Uitvloeisel van hierdie finansiële verknorsing is die skuldgevoelens wat respondente ervaar heh omdat hulle weens hul ekonomiese status nie in staat was om hul voortydse babas te besoek nie. Een respondent het haar gevoelens as volg uitgedruk: "dit is verskriklik om by die huis te wees, en ek weet ek sal nie eers eenker vir die baba kan gaan kuier nie. Ons het nie 'n motor nie, jy weet. Ons het nie eers 'n telefoon nie, so ek kan nie eers bel om te hoor hoe dit gaan nie."

By die beraming van 'n pasiënt moet die

verpleegkundige nooit die behoefte aan ekonomiese stabiliteit buite rekening laat nie. Respondente in die studie se emosionele status is weens hul finansiële bekommernisse nadelig beïnvloed.

\section{BEHOEFTES/PROBLEME MET BETREKKING TOT LIEFDE, AANV AARDING EN SOSIALE VERKEER}

Alle mense het die behoefte om liefde te gee en te ontvang. Hierdie behoefte kan die beste in gesinsverband uitgeleef word. Die geboorte van ' $n$ voortydse baba en die lang periode van hospitalisasie beinvloed die verhouding wat die moeder met haar gesin, vriende, familie en die pasgebore baba het. Die moeder se rol wysig tydens die krisis van ondersteuner na die een wat ondersteuning benodig. Dit veroosaak dat die moeder swaar leun op die ondersteuning van haar gesin, familie, vriende asook die verpleegkundige in wie se sorg sy haar pasgeborene moet toevertrou.

In Tabel 3 word die aantal response wat oor hierdie behoefte handel uitgespel en kan duidelik gesien word hoe groot hierdie behoefte was.

Die moeders het in die eerste plek 'n behoefte aan ondersteuning. Hulle wil iemand hê wat na hulle kan luister en met wie hulle hul gevoelens kan deel (Sammons \& Lewis, 1985:67). Hulle wil veral negatiewe gevoelens, soos die feit dat hul baba vir hul lelik is, met iemand bespreek. Die moeder sien die verpleegkundige wat haar baba versorg. naas haar eggenoot, as haar grootste bron van ondersteuning (Coffman, Levitt \& Deets, 1991:413).

Indien die verpleegkundige hulp verleen met die identifisering en aktivering van ondersteuningsbronne (Coffman et al. 1991:413), kan 'n moeder se gedrag teenoor haar baba (Gennaro, 1985:344), haar selfvertroue in die ouerrol (Zahr, 1991:284) sowel as haar selfbeeld as moeder verbeter. Die behoefte aan ondersteuning wat die respondente in hierdie studie, sowel as die van Affleck. Tennen, Rowe et al. (1989:492) en Crnic, Greenberg, Ragozin et al. (1983:209) geïdentifiseer heth sluit aspekte soos inligting, emosionele empatie en begrip sowel as die hantering van die hospitalisasie van hul babas in.

Respondente in die studie het ook 'n behoefte aan gerusstelling, sowel as die behoefte om daaroor te praat, gehad. Dit sluit baie nou aan by die bevindinge van Molte en Hampe soos beskryf in Jacono, Hicks, Antonioni et al. (1990:74) waar respondente 'n behoefte aan hoop gehad het waaroor hulle graag met iemand wou praar (Leske, 1986: 192; Norris \& Grove, 1986:194-199).

Premature babas en hul moeders ondervind probleme met verbondenheid aangesien die belangrikste periode vir verbondenheid direk na geboorte is. Enige versteuring in hierdie 
TABEL 1: Behoeftes/probleme met betrekking tot inligting

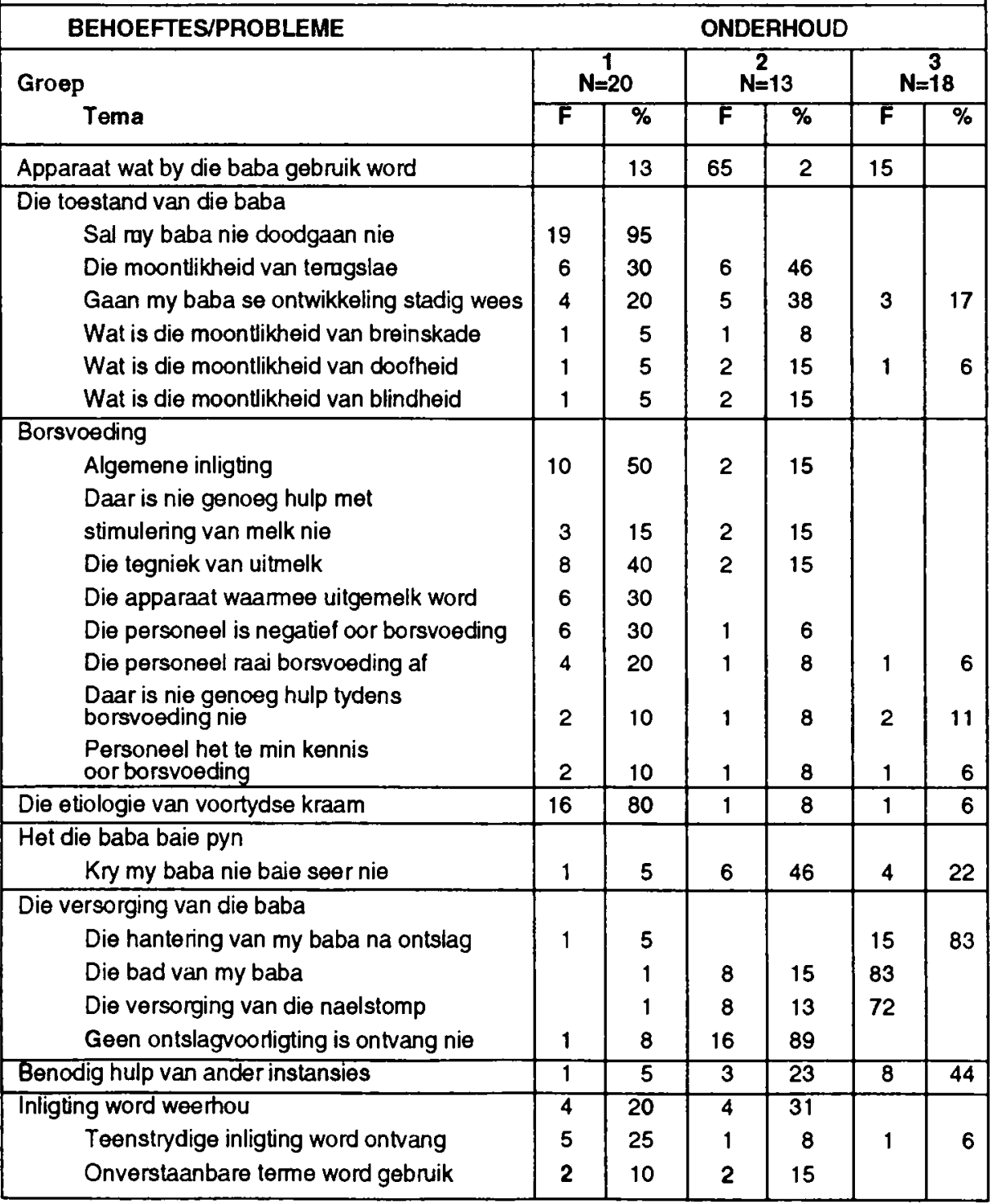

kontak kan die verhouding beïnvloed (Turner, 1988:165). Die voortydse baba benodig onmiddellike gespesialiseerde sorg wat 'n versteuring in hierdie kontak veroorsaak en beïnvloed verbondenheid nadelig. In die studie is bevind dat moeders tot twee dae na die geboorte hul babas vir die eerste keer gesien het. Respondente het gevoel dat hulle aanvanklik nie 'n positiewe verhouding met hul baba gehad het nie. Dit kan wees omdat hulle bang was dat hulle die baba dalk mag verloor (Yellot, 1991:520), of dat hulle nie dadelik hul babas kon sien nie, hulle die baba nie kon aanraak nie, styf vashou of visuele interaksie gehad het nie (Tomlinson, 1990:77; Zahr, 1991:279; Phillips, 1987:231). Baie moeders het gesê dat hulle voel asof hulle apart van hul babas staan en dat bogenoemde probleme die oorsaak daarvan is. Die respondente wat tussen voltydse moeders gehospitaliseer was, was jaloers op die ander moeders omdat hulle hul babas kon vertroetel, vashou en voed.

Indien in ag geneem word dat die moeder van 'n voortydse baba tussen ander voltydse moeders in die nageboortesaal lê, is dit nie vreemd dat respondente jaloers was op die ander moeders nie. Die ander moeders het alle

hou en self te voed gehad. Respothdente was yoed gehad. Respondente was jaloers omdat hulle ook graag so 'n verhouding sou wou hê.

Vier van die respondente in die studie het 'n behoefte ervaar om hul babas aan te trek. Een het gesê: "Is dit nie verskriklik nie. Sy is al twee maande oud en sy het nog nie eers mooi kleertjies aangehad nie. Sy ruik nie eers na 'n ou babatjie nie. Dis alles net hospitaalreuke." Dit is weereens ' $n$ bewys van hoe 'n sterk behoefte die moeder het om haar baba teen haar bors te druk, hom te beruik en te voel dat hy aan haar behoort.

Al die respondente het gemengde gevoelens oor hul ontslag uit die hospitaal gehad, maar wou graag huis toe gaan. Hul ambivalensie is veroorsaak deur die feit dat die baba nog gehospitaliseer was en dat hul eggenoot en ander kinders hul tuis nodig het. Die ander kinders tuis gaan ook deur ' $n$ traumatiese tyd wanneer hul boetie of sussie ' $n$ voortydse baba is. Die lang afwesigheid van hul moeder, die verandering in daaglikse roetine sowel as die verskillende oppassers waaraan hul blootgestel word, maak die gebeurtenis vir hul traumaties (Sammons \& Lewis, 1985:274).

Aangesien 'n kind nie ' $n$ duidelike begrip van tyd het nie (Olds et al. 1988:330) word daar nie lank voor die tyd van die nuwe baba vertel nie. Dit bring mee dat, soos in die studie bevind is, die voortydse baba gebore word nog voordat die moeder kans gehad het om vir die ander kinders van die swangerskap te vertel. Hierdie kinders is dan totaal onvoorbereid op die koms van 'n nuwe baba.

Nie net gedrag soos deur Olds et al. (1988:1139) en Sammons en Lewis (1985:278) beskryf, naamlik slaapversteurings, onttrekking, aggresiwiteit, aandagsoekery, verandering in toiletgewoontes en negatiewe gedrag teenoor die ma het voorgekom nie. Kinders het hul ma beskuldig dat sy ' $n$ leuen vertel het omdat hulle nie die baba kon sien of aanraak nie. Hulle was jaloers, net soos Fortier, Carson, Will et al. (1991:76) in sy studie bevind het, omdat die nuwe baba al die moeder se aandag opgeëis het.

In die studie het die eggenote van die respondente die hospitalisasie van beide die moeder en die baba sleg ervaar. Slegs ee॥ respondent was van mening dat haar eggenoot die situasie beter kon hanteer as syself. Sommige respondente was bekommerd omdat hul eggenote bang was vir die baba, die baba

TABEL 2: Behoeftes/probleme met betrekking tot ekonomiese stabiliteit

\begin{tabular}{|c|c|c|c|c|c|c|}
\hline BEHOEFTES/PROBLEME & \multicolumn{6}{|c|}{ ONDERHOUD } \\
\hline Groep & \multicolumn{2}{|c|}{$\mathrm{N}=20$} & \multicolumn{2}{|c|}{$N^{2}=13$} & \multicolumn{2}{|c|}{$\mathrm{N}=18$} \\
\hline Tema & $F$ & $\%$ & $F$ & $\%$ & $F$ & $\%$ \\
\hline Bekommemis & & & & & & \\
\hline $\begin{array}{l}\text { Hospitaal onkostes is vir my } \\
\text { 'n groot bekommemis }\end{array}$ & 7 & 35 & 2 & 15 & 1 & 6 \\
\hline Hoeveel sal die mediese fonds betaal & 4 & 20 & 2 & 15 & 1 & 6 \\
\hline Ons kan nie self enige kostes betaal nie & 4 & 20 & & & & \\
\hline $\begin{array}{l}\text { Geen finansiole voorsorg is getref nie } \\
\text { Ons het nie hiervoor voorsorg getref nie }\end{array}$ & 3 & 15 & 3 & 23 & 1 & 6 \\
\hline Skuldgovoolens & & & & & & \\
\hline $\begin{array}{l}\text { Ek kon nie my baba in die } \\
\text { hospitaal besoek nie }\end{array}$ & 3 & 15 & 3 & 23 & 1 & 6 \\
\hline $\begin{array}{l}\text { Verplig om weer te gaan werk } \\
\text { Ek moet weer gaan werk }\end{array}$ & 2 & 10 & 3 & 23 & 1 & 6 \\
\hline
\end{tabular}


nie wou aanraak nie, die baba vermy het en die baba selde besoek het. Sammons en Lewis (1985:69) skryf hierdie reaksies toe aan die mate waatoe die man deur die psigologiese ontwikkeling van die derde trimester gevorder het.

Die moeder van 'n voortydse baba is egter nie net van haar gesins-, familielede en vriende afhanklik nie. Sy en haar gesin leef nou saam met die personeel in die spesiale- en neonatale intensiewesorg eenhede. Wortman (1984:2333) beweer dus dat indien 'n pasiënt se hanteringsmeganismes meer effektief is in die teenwoordigheid van ondersteuning van gesins-, familielede en vriende, moet dit ook direk van toepassing wees op die teenwoordigheid van die verpleegkundige in die eenhede.

Respondente het van die personeel verwag om warmte en toegeneentheid uit te straal sodat hulle welkom voel om hul babas te besoek. Die moeders het egter onwelkom gevoel en die personeel as onbetrokke (15 response) en onbelangstellend (sewe response) evaar. Die aanhoudende blootstelling aan swaarkry, dood en 'n persoonlike gevoel van mislukking lei tot psigologiese onttrekking deur personeel. Hierdie selfbeskermende distansiëring word deur ouers waargeneem as 'n traak-my-nie-agtige houding (Sammons \& Lewis, 1985:106). Sommige van die respondente het gesê dat die personeel nie eers lus gelyk het om te help nie.

Volgens Jacono et al. (1990:72) verg lewensreddende aktiwiteite baie tyd van die personeel en gevolglik is daar min geleentheid om die familie te help om die krisis te hanteer. Die moeders, net soos in die studie bevind is, voel dus afgeskeep en voel dat niemand van hulle toestand bewus is nie. Dit reflekteer egter 'n fout in die sisteem (Jacono et al. 1990:76) en bied ' $n$ geweldige uitdaging aan die verpleegkundige om die voortydse baba se moeder te betrek en haar te help om ouerskap in die konteks van die intensiewesorg eenheid te aanvaar (Weingarten, Barker, Manning et al. 1990:64).

Dit is vir die moeder belangrik om die konflik en ambivalensie wat sy ervaar met iemand te bespreek (Sammons \& Lewis, 1985:74), daarom wil sy, net soos ook in die studie bevind is, belangstelling vanaf die kant van die verpleegkundige hê. Die respondente in die studie het gevoel dat personeel sekere vooroordele teenoor hulle koester terwyl Jacono et al. (1990:72) en Leske (1986:192) klem daarop lê dat 'n pasiënt, dit wil sê die moeder van 'n voortydse baba volkome deur personeel aanvaar wil word.

Die verpleegkundige vervul die dominante rol in die verpleegkundige-ouer verhouding aangesien sy in beheer van die omgewing is en oor die nodige kennis beskik. Die ouers beleef angs en stres as gevolg van die veranderde ouerrol wat vereis word (Callery, 1991:780). Dit is dus die verpleegkundige se verantwoordelikheid om as dominante
TABEL 3: Behoeftes/probleme met betrekking tot liefde, aanvaarding en sosiale verkeer

\begin{tabular}{|c|c|c|c|c|c|c|}
\hline BEHOEFTES/PAOBLEME & & & OND & $\mathrm{HOU}$ & & \\
\hline Groep & & & & & & \\
\hline Tema & $\bar{F}$ & $\%$ & $F$ & $\%$ & $\mathbf{F}$ & $\%$ \\
\hline $\begin{array}{l}\text { Ondersteuning } \\
\text { Ek het ondersteuning nodig }\end{array}$ & 13 & 65 & 3 & 23 & 3 & 17 \\
\hline $\begin{array}{l}\text { Gerusstelling } \\
\text { Ek wil so graag gerus gestel word }\end{array}$ & 11 & 55 & 1 & 8 & 3 & 17 \\
\hline $\begin{array}{l}\text { Wil graag oor die ondervinding praat } \\
\text { Ek wil so graag met iemand praat }\end{array}$ & 2 & 10 & 3 & 23 & 2 & 11 \\
\hline $\begin{array}{l}\text { Jaloesie } \\
\text { Ek is jaloers op moeders met } \\
\text { gesonde babas } \\
\text { Ek is jaloers op moeders wat self } \\
\text { hul babas kan voed }\end{array}$ & 10 & $\begin{array}{l}50 \\
40 \\
\end{array}$ & 1 & 8 & $\begin{array}{l}2 \\
2 \\
\end{array}$ & $\begin{array}{l}11 \\
11 \\
\end{array}$ \\
\hline $\begin{array}{l}\text { Verbondenheid } \\
\text { Dit is aanvanklik negatief } \\
\text { Ek kon nie my baba dadelik na } \\
\text { die bevalling sien nie } \\
\text { Ek wou nie my baba self vashou nie } \\
\text { Ek is bang om my baba aan te raak } \\
\text { Ek wil my baba self vashou }\end{array}$ & $\begin{array}{r}13 \\
7 \\
2 \\
19\end{array}$ & $\begin{array}{l}65 \\
35 \\
10 \\
95\end{array}$ & $\begin{array}{l}2 \\
1 \\
1 \\
1 \\
1\end{array}$ & $\begin{array}{l}15 \\
8 \\
8 \\
8 \\
8\end{array}$ & & \\
\hline $\begin{array}{c}\text { Die baba wat sonder klere is, pla baie } \\
\text { Dit pla my dat my baba nog nooit } \\
\text { klere aangehad het nie }\end{array}$ & & & 2 & 15 & 2 & 11 \\
\hline $\begin{array}{l}\text { Die baba veroorsaak sosiale isolasie } \\
\text { Ek kan nie oral gaan met so 'n } \\
\text { klein babatile nie }\end{array}$ & 1 & 5 & 2 & 15 & 2 & 11 \\
\hline $\begin{array}{l}\text { Die ander kinders tuis } \\
\text { Is onvoorbereid op die koms van die baba } \\
\text { Toon regressiewe gedrag } \\
\text { Toon afwykende gedrag } \\
\text { Dink dat ek 'n leuen vertel } \\
\text { Hulle wil ook graag aan die baba raak } \\
\text { Hulle wil ook die baba sien } \\
\text { Is baie jaloers op die nuwe baba }\end{array}$ & $\begin{array}{l}6 \\
2 \\
3 \\
4 \\
7 \\
1\end{array}$ & $\begin{array}{r}30 \\
10 \\
15 \\
20 \\
35 \\
5\end{array}$ & 1 & 8 & $\begin{array}{l}2 \\
3 \\
5 \\
1 \\
2 \\
2 \\
3\end{array}$ & $\begin{array}{r}11 \\
17 \\
28 \\
6 \\
11 \\
11 \\
17\end{array}$ \\
\hline $\begin{array}{l}\text { Haastig om ontslaan te word } \\
\text { Ander kinders tuis het my nodig } \\
\text { My man het my ondersteuning nodig } \\
\text { Ander kinders tuis verlang na my } \\
\text { Ek is verwyder van my gesin } \\
\text { Ek is in 'n tweestryd oor ontslag, } \\
\text { ek wil by my baba bly, maar ek } \\
\text { wil ook huistoe gaan }\end{array}$ & $\begin{array}{r}20 \\
7 \\
3 \\
5 \\
5\end{array}$ & $\begin{array}{r}100 \\
35 \\
15 \\
25 \\
25\end{array}$ & 2 & $\begin{array}{l}31 \\
15\end{array}$ & $\begin{array}{l}1 \\
1\end{array}$ & $\begin{array}{l}6 \\
6\end{array}$ \\
\hline $\begin{array}{l}\text { Eggenoot ervaar die hospitalisasie negatiel } \\
\text { Hy is bang vir die baba } \\
\text { Hy vat nooit aan die baba nie } \\
\text { Hy vermy die baba } \\
\text { Hy besoek nooit die baba nie }\end{array}$ & $\begin{array}{l}4 \\
2 \\
2 \\
2 \\
4\end{array}$ & $\begin{array}{l}20 \\
10 \\
10 \\
10 \\
20\end{array}$ & $\begin{array}{l}3 \\
4\end{array}$ & $\begin{array}{l}23 \\
31\end{array}$ & $\begin{array}{l}1 \\
2 \\
1 \\
1\end{array}$ & $\begin{array}{r}6 \\
11 \\
6 \\
6\end{array}$ \\
\hline $\begin{array}{l}\text { Is kwaad oor eggenoot se onbetrokkenheid } \\
\text { Ek is kwaad omdat my man nie } \\
\text { betrokke is nie }\end{array}$ & 2 & 10 & & & & \\
\hline $\begin{array}{c}\text { Baba se ontslag verander eggenoot se houding } \\
\text { My man gee meer aandag aan die baba } \\
\text { My man is meer positief oor die baba }\end{array}$ & & & & & $\begin{array}{l}3 \\
3 \\
\end{array}$ & $\begin{array}{l}17 \\
17 \\
\end{array}$ \\
\hline $\begin{array}{l}\text { Die personeel se betrokenheid is belangrik } \\
\text { Hulle is onbetrokke by my } \\
\text { Hulle is onbelangstellend in my } \\
\text { Hulle glo nie wal ek sé nie } \\
\text { Hulle is bevooroordeold teenoor my } \\
\text { Hulle lyk nie lus om 'n mens te help nie } \\
\text { Ek voel afgeskeep deur die personeol }\end{array}$ & $\begin{array}{l}5 \\
3 \\
6 \\
4 \\
5 \\
3\end{array}$ & $\begin{array}{l}25 \\
15 \\
30 \\
20 \\
25 \\
15\end{array}$ & $\begin{array}{l}5 \\
3 \\
1 \\
1 \\
2 \\
1\end{array}$ & $\begin{array}{r}38 \\
23 \\
8 \\
8 \\
15 \\
8\end{array}$ & $\begin{array}{l}5 \\
1 \\
1 \\
1 \\
2 \\
2\end{array}$ & $\begin{array}{r}28 \\
6 \\
6 \\
6 \\
11 \\
11\end{array}$ \\
\hline
\end{tabular}


TABEL 4: Behoeftes/probleme met betrekking tot seksuele uitlewing

\begin{tabular}{|l|c|c|c|c|c|c|}
\hline \multirow{2}{*}{ BEHOEFTES/PROBLEME } & \multicolumn{5}{|c|}{ ONDERHOUD } \\
\cline { 2 - 8 } & \multicolumn{2}{|c|}{$N=20$} & \multicolumn{2}{|c|}{$N^{2}=13$} & \multicolumn{2}{|c|}{$\mathbf{N = 1 8}$} \\
\cline { 2 - 8 } & $F$ & $\%$ & $F$ & $\%$ & $F$ & $\%$ \\
\hline Die algehele moegheid is oorweldigend & 1 & 5 & & & 2 & 11 \\
\hline Die baba eis al my aandag & 1 & 5 & & & 4 & 22 \\
\hline Ek het geen libido nie & 1 & 5 & & & & \\
\hline Ons het geen tyd meer vir mekaar nie & 2 & 10 & & & 2 & 11 \\
\hline
\end{tabular}

persoon ondersteuning aan die moeder en haar baba te verskaf.

\section{BEHOEFTES/PROBLEME MET BETREKKING TOT SEKSUELE UITLEWING}

Om holistiese verpleegsorg te lewer moet daar onder andere in die seksuele behoeftes van pasiënte voorsien word. Tog word seksualiteit selde as 'n integrale deel van die behandelingsproses gesien (Zalor, 1982:351). Stuart en Sundeen, soos aangehaal deur Webb (1987:29-30), definieer seksualiteit as 'n integrale deel van elke mens en dit word elke dag van 'n mens se lewe beleef.

Vir die doeleindes van die studie het die navorser die seksuele behoeftes afgebaken tot die verhouding tussen man en vrou aangesien die behoefte aan skoonheid en beeld 'n afsonderlike kategorie is, hoewel dit 'n integrale deel van seksualiteit is. Soos in Tabel 4 gesien kan word, was daar min response oor seksualiteit. Die navorser skryf dit toe aan die voorligting in die plaaslike hospitaal sowel as literatuur wat gemeenskap voor die ses weke ondersoek afraai (Yates, 1987:32). Die moeder van 'n voortydse baba sukkel om haar huiswerk, familieverpligtinge en babasorg te koördineer (Tulman \& Fawceth, 1988:77). Die stres van 'n voortydse baba, die heen en weer ryery hospitaal toe, die uitmelk vir voedings, die versòrging van ander kinders tuis sowel as skuldgevoelens oor die koms van die voortydse baba lei daartoe dat respondente in die studie, net soos in die geval van 'n studie deur Housten (1984:77) oorweldigende moegheid ervaar het. Respondente het ook gevoel dat hul baba al die aandag eis.

Slegs een respondent het genoem dat sy 'n afname in libido ervaar het. Die meeste respondente het egter nog nie hul ses weke ondersoek gehad nie en die bekommernis oor hul baba was vir man en vrou eerste prioriteit.

Respondente in die studie het baie emosionele trauma ondervind aangesien hulle volgens Tabel 6 baie emosionele behoeftes gehad het. Campsey (1985:69) het in sy studie bevind dat pyn, angs en rou veranderlikes is wat seksualiteit en 'n mens se verhouding met ander beïnvloed en daarom kan die navorser nie anders as om te glo dat seksuele probleme wel ondervind is nie. Moontlik is dit nie opgespoor nie omdat die onderhoude voltooi was voor werklike probleme opgeduik het, of die krisis wat die moeder beleef het was so groot dat haar seksuele behoeftes daardeur oorskadu was.

\section{BEHOEFTES/PROBLEME MET BETREKKING TOT SKOONHEID EN BEELD}

Met die beraming van 'n pasiënt moet daar aandag aan 'n pasiënt se behoefte aan skoonheid en beeld gegee word. Tabel 5 weerspieël die omvang van die behoefte.

Ongelukkig is die geboorte van ' $n$ voortydse baba nie bevorderlik vir 'n goeie selfbeeld nie (Sammons \& Lewis, 1985:263). Die ouers van 'n voortydse baba ervaar skuldgevoelens weens verskeie redes (Sammons \& Lewis, 1985:27; While, 1991:18). Soos in bovermelde studies bevind is, het 16 respondente in hierdie studie geglo dat hulle die corsaak was vir die ongelukkigheid van die egpaar. Die feit dat moeders met voortydse babas dikwels saam met moeders met voltydse babas in 'n hospitaalkamer lê herinner hulle aan hul eie mislukking en vererger die emosionele chaos wat met prematuriteit gepaard gaan (Sammons \& Lewis, 1985:72). Meier (1988:36) se studie bevestig dat moeders met voortydse babas skuldgevoelens ontwikkel omdat hul borsvoeding misluk het. Hulle het besluit om te borsvoed, maar is genoodsaak om eers uit te melk. Hul pogings het hul so frustreer dat hul moed opgegee het en dan skuldgevoelens ontwikkel het.

Respondente in die studie het skuldgevoelens gehad omdat hulle reeds tydens hul baba se hospitalisasie moes teruggaan werk toe en dit hul besoeke aan hul baba beperk het.

Van die respondente se babas was nie vir hulle mooi nie. Dit stem ooreen met Sammons en Lewis (1985:67) se mening dat moeders selfs sover gaan om te sê dat hulle eintlik nie die lelike kind wil hê nie, maar hulle soek dan gerusstelling dat hierdie emosie van hulle normaal is.

Wanneer die moeders die neonatale intensiewesorg eenheid besoek het, het hulle oor die algemeen nutteloos en eensaam gevoel. Dit is die produk van gevoelens soos mislukking, vrese vir die dood, breinskade, stres en hartseer (Sammons \& Lewis, 1985:67). Ouers, dit wil sê ook die moeder, het min verantwoordelikheid tydens die hospitalisasie van die baba (Sammons \&

\begin{tabular}{|c|c|c|c|c|c|c|}
\hline \multicolumn{7}{|c|}{ TABEL 5: Behoeftes/probleme met betrekking tot skoonheid/beeld } \\
\hline BEHOEFTES/PROBLEME & \multicolumn{6}{|c|}{ ONDERHOUD } \\
\hline \multirow{2}{*}{$\begin{array}{l}\text { Groep } \\
\text { Tema }\end{array}$} & \multicolumn{2}{|c|}{$N=20$} & \multicolumn{2}{|c|}{$N^{2}=13$} & \multicolumn{2}{|c|}{$N=18$} \\
\hline & $\mathbf{F}$ & $\%$ & $\bar{F}$ & $\%$ & $F$ & $\%$ \\
\hline \multicolumn{7}{|l|}{ Ek het as moeder gelaal } \\
\hline \multirow{2}{*}{\multicolumn{7}{|c|}{ Ek wou so graag self my baba: }} \\
\hline- voed & 20 & 100 & & & & \\
\hline - borsvoed & 15 & 75 & & & 1 & 6 \\
\hline - kunsvoed & 4 & 20 & & & & \\
\hline My borsvoeding het misluk & 1 & 5 & 2 & 15 & 4 & 22 \\
\hline Ek sukkel so mel die borsvoeding & 3 & 15 & 5 & 38 & 3 & 17 \\
\hline Ek is net tot niks in staat nie & 1 & 5 & 1 & 8 & 3 & 17 \\
\hline Ander versorg nou my baba & & & 3 & 23 & 1 & 6 \\
\hline Ek het nie 'n normale bevalling gehad nie & 2 & 10 & & & & \\
\hline \multicolumn{7}{|l|}{ Onbetrokke by die baba } \\
\hline $\begin{array}{l}\text { Onbetrokke by die versorging van } \\
\text { die baba }\end{array}$ & 4 & 20 & 7 & 54 & & \\
\hline Ander mense vervul my rol & 4 & 20 & 7 & 54 & 3 & 17 \\
\hline My baba weet nie ek is sy ma nie & & & 2 & 15 & 2 & 11 \\
\hline \multicolumn{7}{|l|}{$\begin{array}{l}\text { Miskien is die baba self vir sy } \\
\text { toestand verantwoordelik }\end{array}$} \\
\hline Miskien is dit my baba se skuld & & & 1 & 8 & 1 & 6 \\
\hline \multicolumn{7}{|l|}{ Moegheid is 'n probleem } \\
\hline $\begin{array}{l}\text { Die gejaag hospitaal toe en terug } \\
\text { maak n mens moeg }\end{array}$ & 1 & 5 & 5 & 38 & 7 & 39 \\
\hline $\begin{array}{l}\text { Jy moet altyd netjies hospitaal toe } \\
\text { en die netjiese kere pas nog nie }\end{array}$ & & & 1 & 8 & 1 & 6 \\
\hline Ek voel 'n oorlas as ek huip vra & 4 & 20 & 1 & 8 & 2 & 11 \\
\hline $\begin{array}{l}\text { Almal lyk altyd to besig en nie lus } \\
\text { om to help }\end{array}$ & 5 & 25 & 2 & 15 & 2 & 11 \\
\hline $\begin{array}{l}\text { Ek moet alreods tydens die hospitalisasie } \\
\text { van my baba begin werk }\end{array}$ & 1 & 5 & 2 & 15 & 1 & 6 \\
\hline Wil nie graag my baba so onthou nie & & & 3 & 23 & 6 & 33 \\
\hline
\end{tabular}




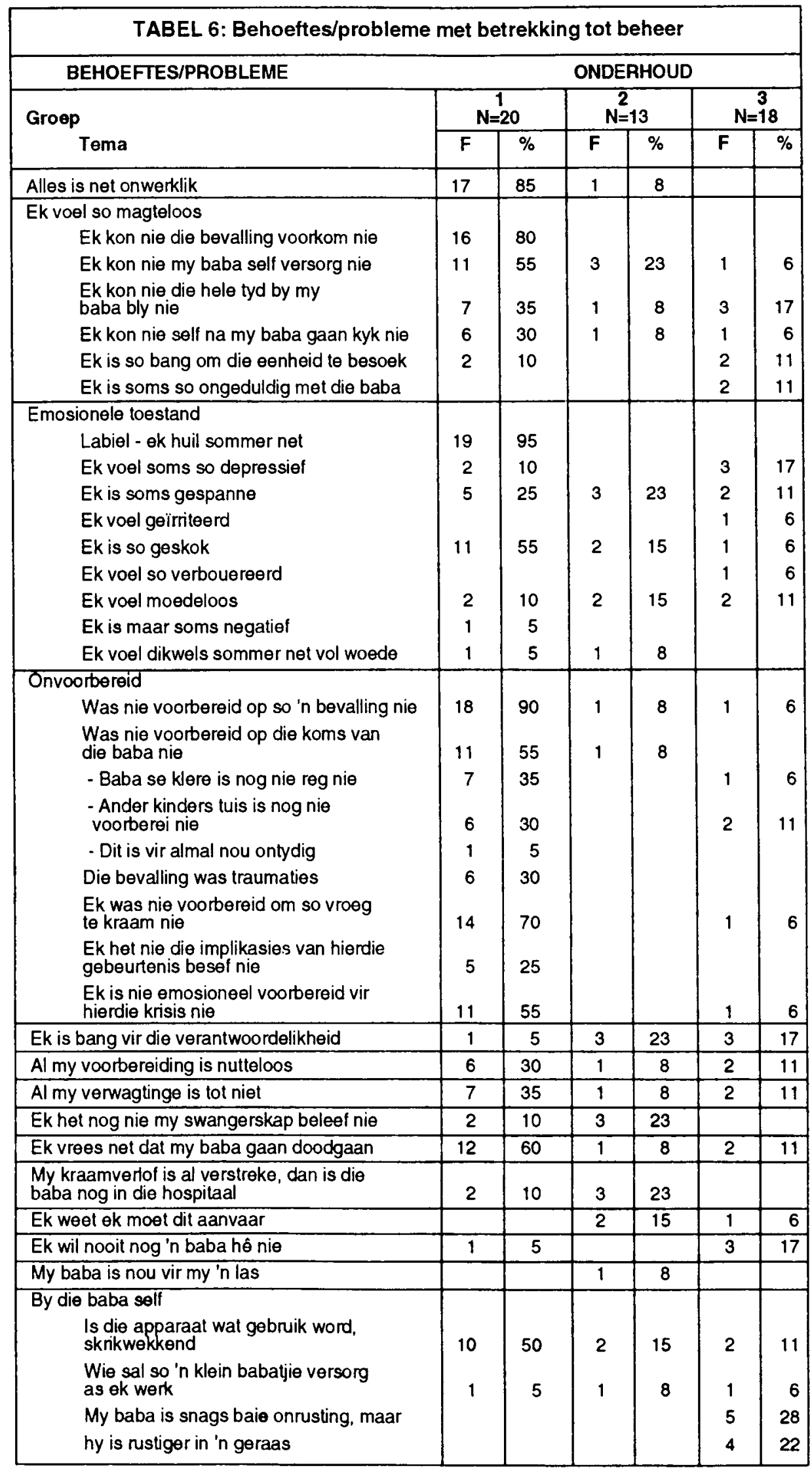

Lewis, 1985:191) en die respondente het dit as onbetrokkenheid ervaar.

Dic navorser is van mening dat die verpleegkundige hierdie emosies by die ouers moet kan identifiseer en hulle behoefte aan skoonheid en beeld in haar verpleegsorg integreer. Die moeder se behoefte om weer sukses te behaal en haar selfbeeld te verbeter kan sodoende aangespreek word.

\section{BEHOEFTES/PROBLEME MET BETRE KKING TOT BEHEER}

Volgens Clarke, soos aangehaal deur Sims (1987:583), ervaar 'n persoon beheer oor 'n situasie wanneer die vermoë om dit te hanteer groter is as die eise wat deur situasie gestel word. Die verlies aan beheer gee aanleiding tot 'n gevoel van hulpeloosheid (Sims, 1987:584; Blackburn \& Lowen, 1986:175) en afhanklikheid (Wright, 1985:10). In Tabel 6 word die response rakende die behoefte aan beheer weergegee.

Die voortydse geboorte van ' $n$ baba is ' $n$ krisis $v$ ir die ouers en respondente in die studie het 'n gevoel van magteloosheid geïdentifiseer. Yellot (1991:519) en Blackburn en Lowen (1986:175) beskryf dat die geboorte van 'n voortydse baba, behalwe die ander emosies, ook gevoelens van hulpeloosheid teweeg bring. Respondente was magteloos omdat hulle nie die bevalling kon voorkom nie, nie self die baba kon versorg nie, of by hom/haar bly nie. Hulle wou die eenheid besoek, maar was bang om dit te doen.

Moeders moet na die geboorte van 'n voortydse baba nie net met die normale ontwikkelingskrisis (Gennaro, 1988:214) as gevolg van prematuriteit en die siektes wat daarmee gepaard gaan, rekening hou nie. Hulle moet ook hul gefantaseerde ouerrol herdefinieer na die beperkinge van die ouerrol in die neonatale intensiewe of die spesialesorg eenheid (Kolotylo et al. 1991:146).

Die navorser kan nie in woorde die emosionele krisis wat respondente ervaar het, beskryf nie. Die literatuur soos beskryf deur onder andere While (1991:18), Houston (1984:76), Grieve (1990:24) en Gennaro (1988:214) erken die angs wat 'n ma van 'n voortydse baba beleef, maar niemand beskryf die mate waarin hierdie angs teenwoordig is nie, ook nie die spanning waraan hierdie moeders onderworpe is nie. Volgens Crnic et al. (1983:214) het hierdie stres of spanning ' $n$ negatiewe impak op ouerskap. Sy het bevind dat moeders wat stres ervaar het, minder positiewe gevoelens teenoor hul babas gehad het en minder op hul babas se gedrag gereageer het. Respondente het ook gekla oor depressie, soos Gennaro (1988:214), Phillips (1987:241) en Kolotyloet al. (1991:146) ook meld.

Om die ouers voor te berei op die mees ontstellende aspekte, kan volgens die mening van die navorser sowel as Auvenshine en Enriquez (1990:786) van groot waarde wees. Die probleme waarmee respondente te doen gehad het omdat hulle onvoorbereid was, word ook deur Auvenshine en Enriquez beskryf. Respondente was onvoorbereid op die tegnologie en daarom wou hulle meer inligting oor apparaat bekom.

Hulle was emosioneel onvoorbereid op die koms van die baba. Sewentig present van die respondente het geverbaliseer dat hul geensins op die moontlikheid van voortydse baring voorberei was nie. Vir $25 \%$ van die respondente was die implikasies van voortydse baring totaal onbekend. Ten spyte van die feit dat sommige hulle daarop probeer voorberei het, was hul voorbereiding volgens hulle nutteloos en hul verwagtinge tot niet.

Die moeders van voortydse babas baseer dikwels hul verwagting ten opsigte van gedrag en voorkoms op dié van die voltydse baba (Harrison \& Twardosz, 1986:165). Al aanvaar 
hul later hul voortydse baba, soos respondente wel gedoen het, vergelyk hulle hul nog dikwels ongunstig met 'n gesonde voltydse baba of met die ander kinders tuis (Grieve, 1990:25).

Selfs die swangerskap was vir respondente 'n probleem omdat dit reeds beëindig is voordat hulle werlik hul swangerskap beleef het. Die ongemaklikheid van die laaste trimester van swangerskap, wat by hierdie moeders ontbreek, speel ' $n$ baie belangrike rol. As al die wonderlike psigologiese aspekte van die tweede trimester sou voortduur, sou niemand hul swangerskap wou beëindig nie (Auvenshine \& Enriquez, 1990:226). Die navorser sien dit as een van die redes waarom respondente van mening was dat hul nog nie hul swangerskap beleef het nie.

Om 'n voortydse baba te hê, is en bly 'n slegte ervaring, ook vir respondente in hierdie studie. Selfs in die weke na ontslag kan moeders nog met die krisis van baring en die neonatale intensiewesorg eenheid gemoeid wees. Die elemente van die hoog tegnologiese omgewing waarin hulle was, sowel as die bekommernis oor die oorlewing van die baba, bly hulle by (Affleck et al. 1989:489).

Met die beraming van ' $n$ pasiënt se bekommernis oor en die teenwoordigheid van die verlies aan beheer, moet daar dus besondere aandag gegee word aan die ervaring van ' $n$ moeder se persepsie van die hospitalisasie van haar baba en aan al die genoemde behoeftes en probleme wat geidentifiseer is.

\section{BEHOEFTES/PROBLEME MET BETREKKING TOT GODSDIENS}

Simsen en Burnard (1988:30) haal Florence Nightingale aan en noem dat die gees en dus die geestelike behoeftes wat die godsdienstige behoeftes van die mens insluit, van net soveel belang vir die algemene gesondheid van die mens is as die fisieke organe waaruit die liggaam saamgestel is. ' $n$ Nog meer omvattende mening is dié van Labun (1988:314) wat reken dat die gees van die mens die aspek van die totale mens is wat elke aspek van menswees kan beïnvloed.

As die liggaam van die mens bespreek word kan dit direk van toepassing gemaak word op die moeder van 'n voortydse baba. Sy sien haar baba as uitvloeisel van haar eie liggaam en daarom beleef sy die siekte van haar baba so intens. In hierdie lig beskou sal die noue interaksie wat tussen die gees en die liggaam van die mens bestaan, veroorsaak dat ' $n$ negatiewe belewenis van enige van die twee komponente ' $n$ effek op die ander komponemt uitoefen (O'Brien, 1982:69). Die moeder se geestelike gesondheid word dus deur haar baba se siektetoestand beïnloed. Respondente het volgens tabel 7, wat die geestelike behoeftes aanspreek, hierdie beginsel gestaaf.

Vrae wat deur respondente gevra is, stem

TABEL 7: Behoeftes/probleme met betrekking tot godsdiens

\begin{tabular}{|c|c|c|c|c|c|c|}
\hline \multirow{3}{*}{$\begin{array}{l}\text { BEHOEFTES/PROBLEME } \\
\text { Groep } \\
\text { Tema }\end{array}$} & \multicolumn{6}{|c|}{ ONDERHOUD } \\
\hline & \multicolumn{2}{|c|}{$\begin{array}{c}1 \\
N=20\end{array}$} & \multicolumn{2}{|c|}{$N_{=13}^{2}$} & \multicolumn{2}{|c|}{$N=18$} \\
\hline & $\mathbf{F}$ & $\%$ & $\mathbf{F}$ & $\%$ & $\mathbf{F}$ & $\%$ \\
\hline Geloof & & & & & & \\
\hline Ek bid so baie & 3 & 15 & 1 & 8 & 1 & 6 \\
\hline Die Here sal vir my kind sorg & 3 & 15 & & & & \\
\hline Ek het so geglo dat dit sal goed gaan & 1 & 5 & & & & \\
\hline Dit het my nader aan God gebring & 1 & 5 & 1 & 8 & 1 & 6 \\
\hline Ek is kleingelowig & 2 & 10 & 1 & 8 & & \\
\hline Straf & & & & & & \\
\hline Beproel die Here my? & 6 & 30 & & & & \\
\hline Straf die Here my? & 2 & 10 & & & & \\
\hline Waarom het dit met my gebeur? & 11 & 55 & & & & \\
\hline $\begin{array}{l}\text { Opstand } \\
\text { Ek is soms opstandig }\end{array}$ & 1 & 5 & & & & \\
\hline $\begin{array}{l}\text { Tyd } \\
\text { Ek het by die huis amper nie } \\
\text { meer tyd vir godsdiens nie }\end{array}$ & & & & & 3 & 17 \\
\hline
\end{tabular}

ooreen met die wat deur Ferszt en Tayler (1988:48), Highfield en Cason (1983:187) en Stol (1979:1574), bespreek is. Die geestelike dimensie van die mens omsluit die behoefte om betekenisvolle antwoorde te verkry op vrae soos die betekenis van die lewe, die betekenis van siekte, soos dié van 'n voortydse baba en die betekenis van die dood. Vir moeders van voortydse babas is die dood van hul baba ' $n$ werklikheid en respondente het dit gevrees. Die krisissituasie waarin die moeder van 'n voortydse baba verkeer, bring haar van aangesig tot aangesig met die beperkings van die mens. Die hoekom en waarom vrae het ook by die respondente ontstaan. Respondente het geverbaliseer dat dit moontlik straf (Labun, 1988:317; Geyer, 1980:19) kan wees vir iets wat hulle verkeerd gedoen het. Dit wil sê dat God 'n Regter is en 'n oog vir 'n oog eis (Stol, 1979:1575).

Sommige het hierdie gebeurtenis as 'n beproewing gesien. Dit is dan vir hulle die rede waarom God hierdie dinge toelaat. Respondente het geglo dat God hul babas sou gesond maak, tog het hul kleingelowig gevoel.

Uit bogenoemde bespreking is dit duidelik dat 'n moeder met 'n voortydse baba 'n verskeidenheid van geestelike behoeftes het. Met verpleegkundige beraming speel die verpleegkundige ' $n$ unieke rol om hierdie behoeftes te identifiseer as 'n holistiese benadering in verpleegsorg gevolg word. Interpersoonlike ondersteuning (Murawski, Penman \& Schmitt, 1987:366), aanmoediging, empatie en luister (Peck, 1981:159) kan 'n klimaat skep waarin geloof groei. Godsdiens kan 'n bron word waaruit krag en sterkte, wat hierdie moeders so nodig heh geput kan word.

\section{AANBEVELINGS EN SAMEVATTING}

Figuur 3 illustreer die verspreiding van behoeftes tydens die eerste onderhoud. Dit is dus behoeftes wat reeds tydens die hospitalisasie van die moeder geïdentifiseer is en is dit die verantwoordelikheid van die verpleegkundiges in die hospitaal om in hierdie behoeftes te voorsien.

Volgens Figuur 4 was die behoefte aan inligting die oorheersende behoefte tydens die derde onderhoud. Die grootste persentasie van die response het oor die versorging van hul babas gehandel. Die moeders moet voor ontslag van hul babas aktief aan die versorging in die eenhede begin deelneem sodat hulle ervaring kan opdoen en in babasorg onderrig kan word. Die gemeenskapsverplecgkundige moet egter ' $n$ baie groot ondersteunende rol tuis vervul.

'n Deeglike beramingsinstrument, wat tot effektiewe voorbereiding, verpleegsorg en voorligting tydens die voor-en nageboortetydperk aanleiding sal gee, behoort hierdie behoeftes te ondervang. Indien die verpleegkundige dus wil roem op holistiese verpleegsorg, sal daadwerklik hieraan aandag gegee moet word.

\section{'N VOORBEREIDINGSPROGRAM VIR MOEDERS IN 'N VOORGEBOORTE SAAL}

Vanuit die navorsing blyk dit baie duidelik dat deeglike pasiëntvoorbereiding 'n groot persentasie van die geïdentifiseerde behoeftes sou ondervang. Respondente was geheel en al onvoorbereid op voortydse baring en die gevolge daarvan. Dit is dus duidelik dat verpleegkundiges met hul beraming nie aandag aan alle aspekte van menswees gegee het nie.

Dit sou baie voordele vir die moeder, haar gesin sowel as die verpleegkundige inhou, indien ' $n$ beramingsinstrument daargestel kon word. Hierdie navorsingsresultate gee 'n baie goeie anduiding van die psigiese-, psigososiale-, godsdienstige-, seksuele- en ekonomiese behoeftes wat hierdie moeders ervaar. Aangesien hierdie behoeftes in die 

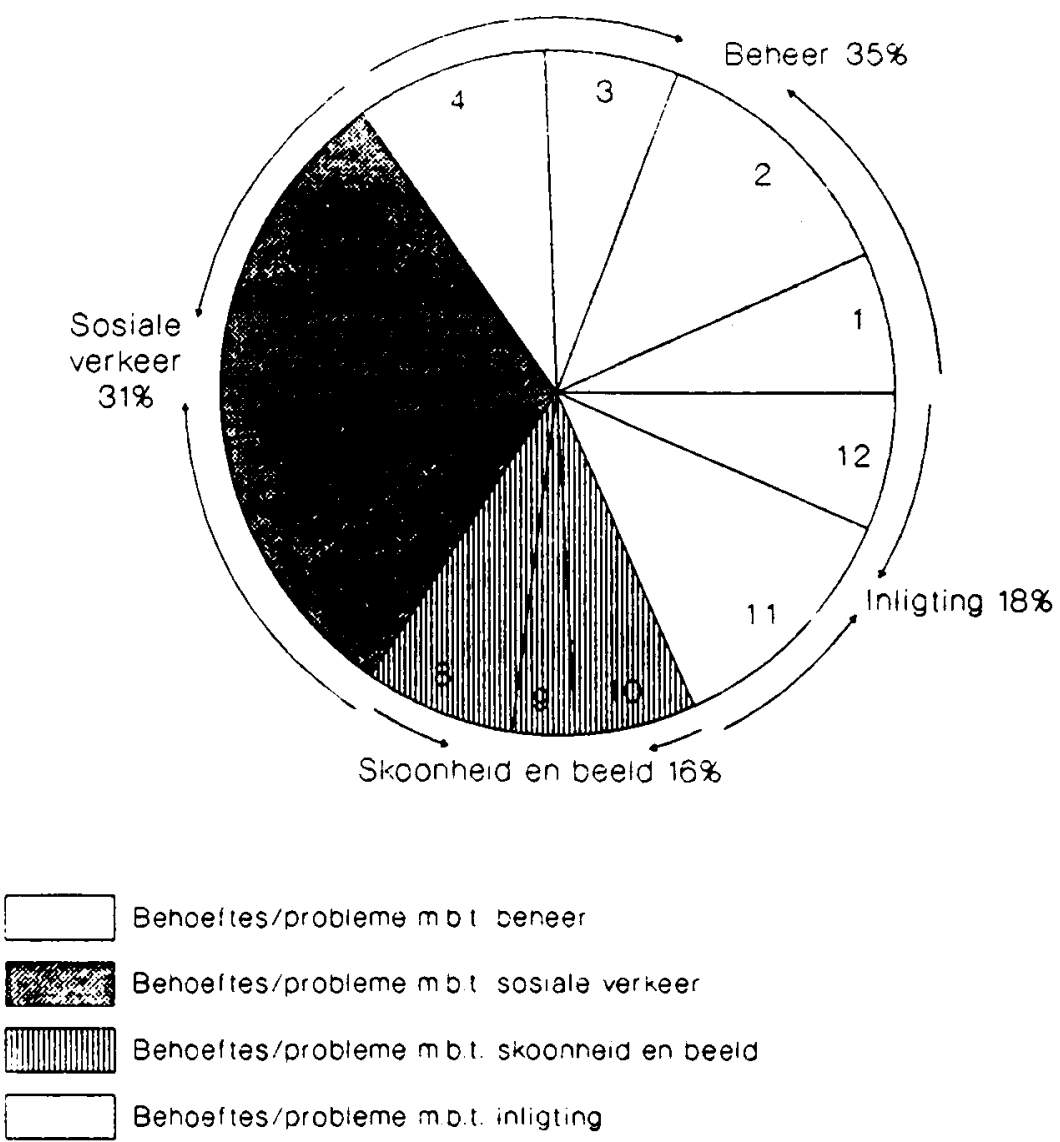

Benoelles/probleme mol beneer

Benoeltes/probleme m b. sosıle verkeer

Benoeltes/probleme mb.t. skoonneid en Deeld

Benogftes/probleme mo.t. inligting

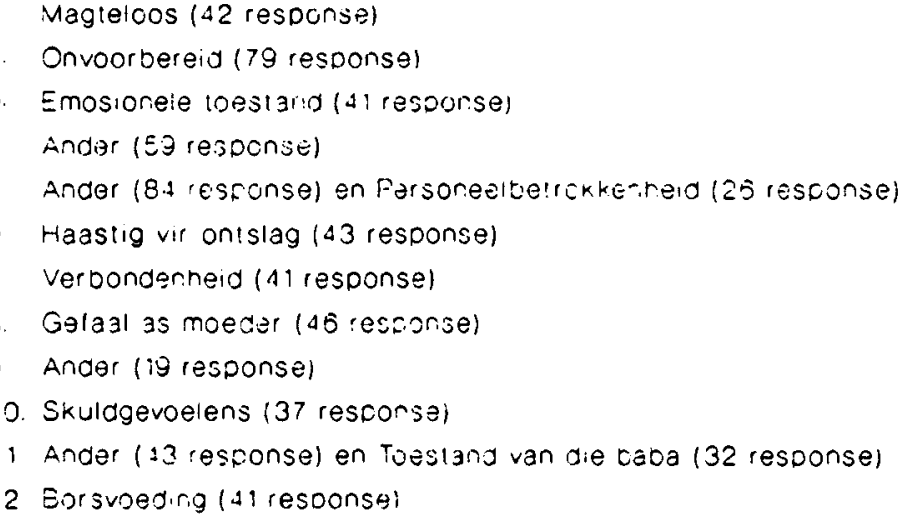

\section{FIGUUR 3: Die verspreiding van behoeftes tydens die eerste onderhoud}

werklike situasie deur die moeders geidentifiseer is, sonder dat enige leidende vrae gevra is, kan aangeneem word dal dit die werklike behoeftes van moeders van voortydse babas is. Met hierdie navorsingsresultate as rugsteun en hulp, kan daar nou 'n gestruktureerde beramingsinstrument vir hierdie moeders opgestel word. Dit sal tot optimale voorbereiding en verpleegsorg aanleiding gee. Ten einde 'n volledige beramingsinstrument daar te stel, moet die fisieke behoeftes ingesluit word.

Vir die verpleegkundige in die voorgeboortesaal moet hierdie beramingsinstrument as hulp dien om die moeder vir voortydse baring en dit wat daarop volg, voor te berei. Die navorsingsresultate toon dat die moeders onvoorbereid was op, byvoorbeeld die bevalling. Hulle het die apparaat wat by die baba gebruik word as skrikwekkend ervaar. Die neonatale intensiewesorg enheid en die voorkoms van hul babas was vreemd. Hierdie, en nog baie meer, is behoeftes waaraan daar in ' voorbereidingsprogram aandag gegee moet word. Al sou 'n moeder vir slegs een dag voor baring gehospitaliseer word, kan hierdie dag optimaal vir voorbereiding benut word. Op dié manier behoort baie behoeftes soos dié aan beheer, inligting, skoonheid en beeld en sosiale verkeer wat so uitgesproke tydens die eerste onderhoud was, ondervang te word (Figuur 3).

So ' $n$ beramingsinstrument sal net van waande wees as dit deur sowel die verpleegkundiges in die voor- en nageboortesale en die eenhede gebruik word. Indien dit so gebruik word, sal alle verpeegkundiges wat by die moeder van 'n voortydse baba betrokke is, bewus gemaak word van die behoeftes sodat hulle aandag daaraan kan gee. Die moeder van 'n voortydse baba sal dan nie soos dié in die studie, soveel behoeftes hê waaraan daar nooit aandag gegee word nie.

\section{ONDERSTEUNINGSGROEP VIR MOEDERS (OUERS) VAN VOORTYDSE BABAS}

In die krisis van voortydse baring sowel as die angs en hartseer wat daarop gevolg het, het ouers in die studie pynlik alleen gevoel. Dit sou baie maklik wees om dan heeltemal geïsoleer en teruggetrokke te raak. Op die manier maak hulle dit dan ook vir die wat wil help moeilik om hulp te verleen.

Dit is vir ouers, en veral die moeders, moeilik om te aanvaar dat hoewel hul ervaring uniek is, daar tog sekere aspekte is wat ooreenstem met die ervaring van ander ouers met voortydse babas. Om hierdie alleenheid te verminder is daar alreeds hospitale wat met ondersteuningsgroepe vir ouers begin het. Die navorser beveel dan, net soos Grieve (1990:25) en Sammons en Lewis (1985:321) ondersteuningsgroepe vir hierdie ouers aan. So 'n ondersteuningsgroep behoort deur ' $n$ verpleegkundige, 'n maatskaplike werker of enige ander lid van die gesondheidspan gelei te word. Die leier moet egter ervaring in groepleierskap, groepsdinamika, genoeg kennis van die mediese aspekte in die neonatale intensiewesorg-en die spesialesorg eenhede, psigologiese aspekte van ouerskap en die gedragsontwikkeling van ' $n$ voortydse baba hê.

Die ondersteuningsgroep moet veral tydens hospitalisasie van die baba aktief wees. Die moeders (ouers) van voortydse babas het egter in die navorsing getoon dat hulle tyd beperk is en dat hulle moeg is van die heen en weer ry hospitaal toe. Die navorser is dus van mening dat indien 'n ondersteuningsgroep werklik van waarde wil wees, dit by die hospitaal, juis wanneer ouers hul babas kom besoek, moet funksioneer.

'n Vertrek behoort ingerig te word waar ouers in privaatheid of in groepe met mekaar en die mediese personeel kan praat. Voorligtingsmateriaal in die vorm van boeke, foto's en videomateriaal moet hier beskikbaar wees, sodat ouers voorberei kan word vir wat dalk nog kan gebeur. Ouers het dan 'n plek waar hulle, saam met die groepleier ook hul gevoelens met ander ouers kan deel. Ouers het dikwels nodig om aan hul emosies uiting te gee, maar het selde die geleentheid daartoe omdat daar in die hospitaal en dikwels tuis 'n gebrek aan privaatheid is. So 'n vertrek, kan vir emosionele ontlading gebruik word.

Nadat die aanvanklike akute krisis verby is volg die ontslag. Tydens hierdie fase is dit net so belangrik om iemand te hê met wie 


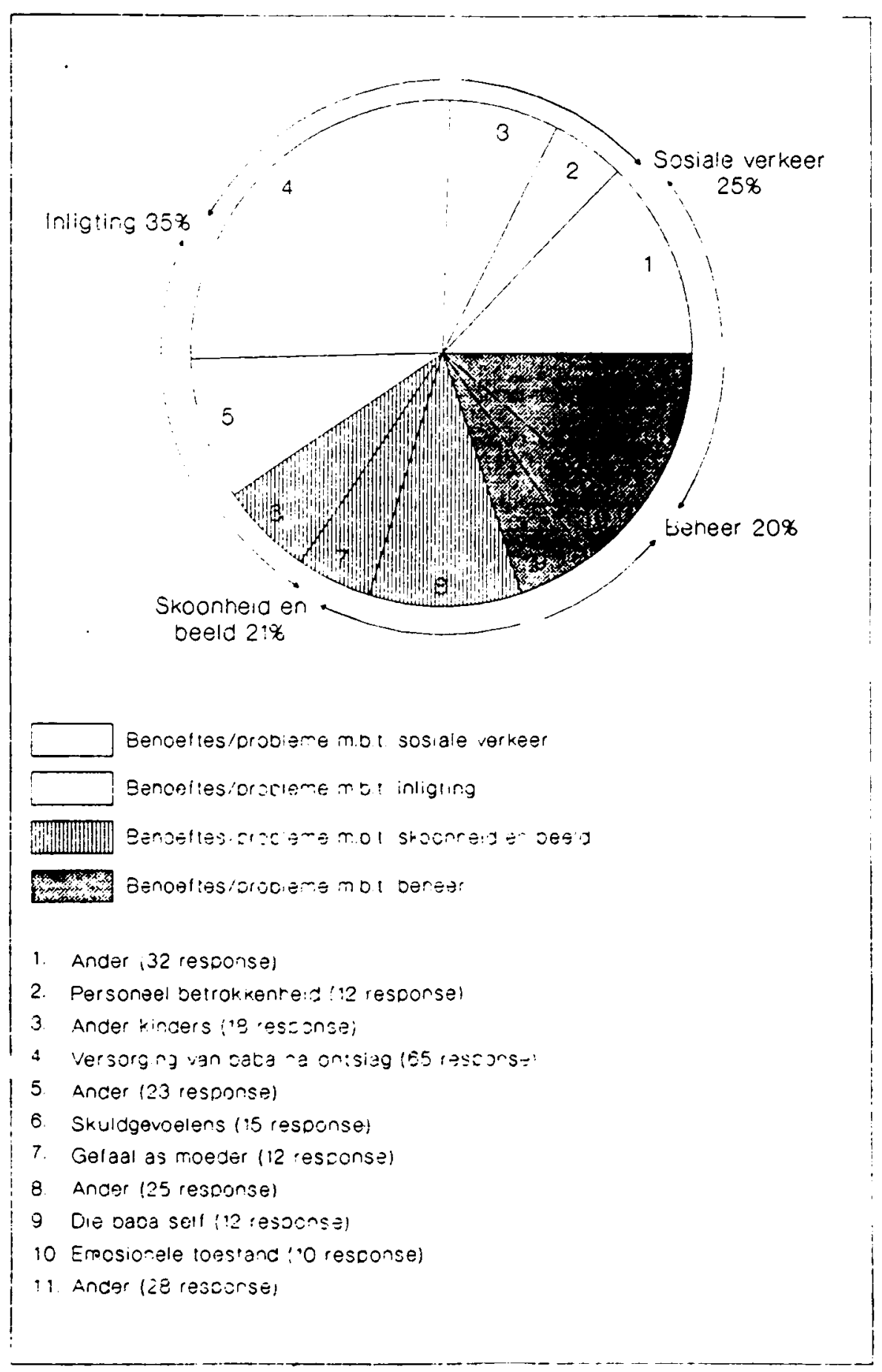

FIGUUR 4: Die verspreiding van behoeftes tydens die derde onderhoud

ervarings en advies gedeel kan word. Hierdie behoefte is duidelik in die navorsing geidentifiseer waar respondente tydens die derde onderhoud, (Figuur 4) wat ná ontslag van die baba plaasgevind het, behoeftes veral ten opsigte van inligting (88 response) en sosiale verkeer (62 response) geidentifiseer het. Nie net die navorser nie, maar ook Turner (1988:162) beveel so ' $n$ ondersteuningsgroep wat ook na ontslag funksioneer, aan.

\section{SAMEVATTING}

Die aanbevelings dra soveel meer krag as die belewenis van die respondente in die studie in ag geneem word, naamlik dat dit baie gehelp het om, terwyl hulle in die krisis was, met iemand oor hulle behoeftes en ondervinding te praat. Vandaar die bereidwilligheid van elke familie werk, as aansporing om te volhard, dien.

\section{BRONNELYS}

Affleck, G., Tennen, H., Rowe, J., ROSCHER, B. \& WALKER, L. (1989). Effects of formal support on mothers' adaptation to the hospital-to-home transition of high-risk inf ants: The benefits and costs of helping. Child Development, 60:488-501.

Auvenshine, M.A. \& Enriquez, M.G. (1990). Perinatal and womens' health. 2nd ed. Boston: Barlett Publishers Inc.

Blackbum, S. \& Lowen, L. (1986). Impact of an inf ant's premature birth on the grandparents and parents. Joumal of Obstetric, Gynecologic and Neonatal Nursing, 15(2):173-178.

Bliss-Holtz, V.J. (1988). Primiparas prenatal concern for leaming infant care. Nursing Research, 37(1):20-24.

Bums, N. \& Grove, S.K. (1987). The practice of nursing research/conduct, critique and utilization. Philiadelphia: W.B. Saunders Co.

Callery, P. (1991). A study of role negotiation between nurses and the parents of hospitalized children. Journal of Advanced Nursing. 16:772-781.

Campsey, J.R. (1985). The sexual dimension of patient care. Nursing Forum, 22(2):69-71.

Coffman, S., Levitt, M.J. \& Deets, C. (1991) Personal and professional support for mothers of NICU and healthy newborns. Journal of Obstetric, Gynecologic and Neonatal Nursing. 20(5):406-414.

Collin, M.F., Halsey, C.L. \& Anderson, G.L. (1991) Emerging developmental sequelae in the normal extremely low birth-weight infant. Pediatrics, 88(1):115-119.

Cmic, K.A., Greenberg, M.T. \& Ragozin, A.S. Robinson, N.M.\& Basham, R.B. (1983). Effects of stress and social support on mothers and premature and full-term infants. Child Development, 54:209-217.

Ferszt, G.G. \& Taylor, P.B. (1988). When your patient needs spiritual comfort. Nursing, 84(4):48-49.

Fortier, J.C., Carson, V.B., Will, S. \& Shubkragel B.L (1991). Adjustment to a newbom. Joumal of Obstetric, Gynecologic and Neonatal Nursing, 20(1):73-78.

Funch, D.P. \& Mettlin, C. (1982). The role of support in relation to recovery from breast surgery. Social Science and Medicine, 16:91-98.

Gennaro, S. (1985). Maternal anxiety, problem-solving ability, and adaptation to the premature infant. Pediatric Nursing. 11:343-348.

Gennaro, S. (1988). Postpartal anxiety and depression in mothers of term and preterm inf ants. Nursing Research, 37(4):214-216.

Geyer, N. (1980). Steungewingsmomente in die verpleging van in pasiënt met eindstadiumnierversaking. Pretoria: Die Suid-Afrikaanse Verpleegsters-vereniging.

Grieve, K. (1990). The role of the nursing staff in promoting the development of preterm infants through their contribution to mother-infant interaction. Curationis, 13(1,2):24-28. 
Harrison, L. \& TwarDosz, S. (1986). Teaching mothers about their preterm infants. Joumal of Obstetric, Gynecologic and Neonatal Nursing, 165-171.

Highfield, M.F. \& Cason, C. (1983). Spiritual needs of patients: Are they recognized? Cancer Nursing, 6(3):187-192.

Houston, M.J. (1984). Matemal and infant health care. Singapore: Selector Printing Co. Ltd.

Jacono, J., Hicks, G., Antonioni, C., O'Brien, K. \& Rasi, M. (1990). Comparison of perceived needs of family members between registerd nurses and family members of critically ill patients in intensive care units. Heart and Lung, 19(1):72-78.

Kirk, J. \& Miller, M.L. (1986). Reliability and validity in qualitative research. Beverly Hills: SAGE Publications.

Kolotylo, C.J., Parker, N.1.\& Chapman, J.S. (1991). Mothers perceptions of their neonates in hospital transfers from a neonatal intensive care unit. Joumal of Obstetric, Gynecologic and Neonatal Nursing, 20(2):146-152.

Labun, E. (1988). Spiritual care: an element in nursing care planning. Joumal of Advanced Nursing, 13:314-320.

Lee, S.K., Penner, P.L. \& Cox, M. (1991). Impact of very low birth weight infants on the family and its relationship to parental attitudes. Pediatrics, 88(1):105-109.

Leske, J.S. (1986). Needs of relatives of critically ill patients: A follow-up. Heart and Lung. 13:189-193.

LoBiondo-Wood, G. \& Haber, J. (1990). Nursing research, methods, critical approval, and utilization. 2nd ed. St Louis: The C.V. Mosby Co.

Meier, P. (1988). Bottle- and breast-feeding: Effects on transcutaneous oxygen pressure and temperature in preterm infants. Nursing Research, 37(1):36-41.

Miles, M.B. \& Huberman, A.M. (1984). Qualitive data analysis. 2nd ed. London: SAGE Publications Lid.

Minshull, J., Ross, K. \& Tumer, J. (1986). The human needs model of nursing. Joumal of Advanced Nursing, 11(6):643-649.

Mouton, J., Ferreira, M., Puth, G., Schurink, S.J. \& Schurink, E.M. (1988). Inleiding tot kwalitatiewe metodes, Module 3. Pretoria: Raad vir Geesteswetenskaplike Navorsing.
Murawski, B.J., Penman, D. \& Schmitt, M. (1987). Social support in health and illness: The concept and its measurement. Cancer Nursing.

Nel, W.E. (1989). Pre-Operatiewe rehabilitasie van koronêrevaatomleidingspasiënte. Magister Curationis, Randse Afrikaanse Universiteit, Johannesburg.

Norris, L. \& Grove, S. (1986). Investigation of selected psychosocial needs of family members of critically ill adult patients. Heart and Lung, 15:194-199.

O'Brien, M.E. (1982a). Religious faith and adjustment to long-term hemodialysis. Joumal of Religion and Health, 20(1):68-80. Olds, S.B. London, M.L. \& Ladewig, P.A. (1988). Matemal-newbom nursing. 3rd ed. Menlo Park: Addison-Wesley Publising Co.

Peck, M.L. (1981). The therapeutic effect of faith. Nursing Forum, XX(2):153-165.

Perlman, N. B., Freedman, J.L., Abramovitch, R. Whyte, H., Kirpalani, H. \& Perlman, M. (1991). Infomational needs of parents of sick neonates. Pediatrics, 88(3):512-517.

Phillips, C.R. (1987). Family - centered matemity/newbom care. 2nd ed. St Louns: The C.V. Mosby Co.

Sammons, W.A.H. \& Lewis, J.M. (1985). Premature babies, a different beginning. $\mathrm{St}$ Louis: The C.V. Mosby Co.

Sandelowski, M. (1986). The problem of rigor in qualitative research. Advances in Nursing Science, 8(3):27-37.

Shepp, K.G. (1991). Factors influencing the coping effort of mothers of hospitalized children. Nursing Research, 40(1):42-45.

Sims, S.E. R. (1987). Relaxation training as a technique for helping patients cope with experience of cancer: A selective review of the literature. Journal of Advanced Nursing. 12(5):583-591

Simsen, B. \& Bumard, S. (1988). Nursing the spirit. Nursing Times, 84(37):30-33.

Stol, R.1. (1979). Guidelines for spiritual assessment. American Joumal of Nursing. 79(9):1574-1577.

Tomlinson, P.S. (1990). Verbal behavior associated with indicators of matemal attachment with the neonate. Joumal of Obstetric, Gynecologic and Neonatal Nursing, 19:76-77. Tulman, L. \& Fawcett, J. (1988). Retum to functional ability after childbirth. Nursing Research, 37(2):77-78.
Tumer, V. (1988). The needs of babies discharge from special care baby units: A subject review. Intensive Care Nursing, 4:160-168.

Webb, C. (1987). Sexual healing. Nursing Times, 83(32):29-30.

Weingarten, C.T., Baker, K., Manning, W. \& Kutzner, S.K. (1990). Married mothers" perceptions of their premature or term infants and the quality of their relationships with their husmands. Joumal of Obstetric, Gynecologic and Nernatal Nursing, 19(1):64-71.

While, A. (1991). Caring for children: Towards a partnership with families. London: Hodder \& Stoughton.

Wilson, H.S. (1989). Research in nursing. 2nd ed. Addison-Wesley Publishing Co., Califomia.

Wortman, C.B. (1984). Social support and the cancer patient: Conceptual and methodologic issues. Cancer, 53(10):2339-2357.

Wright, L.K. (1985). Life threatening illness. Journal of Psychosocial Nursing, 23(9):7-11.

Yates, A. (1987). And baby makes three. Nursing Times, 83(32):31-33.

Yellott, G. (1991). Promoting parent-infant bonding. Professional Nurse, 6(9):519-523.

Yura, H.\& Walsh, M.B. (1982). Human needs 2 and the nursing process. Norwalk: Appleton-Century-Crofts.

Zahr, L.J. (1991). The relationship between maternal confidence and mother-infant behaviors in premature infants. Research in Nursing and Health, 14:279-286.

Zalor, M.K. (1982). Role preparation for nurses in human sexual functioning. Nursing Clinics of North America, 17(3):351-363. 